Available online on 15.3.2018 at http://ujpr.org
Universal Journal of Pharmaceutical Research
An International Peer Reviewed Journal
Open access to Pharmaceutical research

\title{
THE ROLE OF DIGITAL MARKETING IN MEDICAL TOURISM INDUSTRY IN POINT OF VIEW OF MEDICAL TOURISM POLICY MAKERS OF SHIRAZ IN 2017 \\ Abbas Yazdanpanah ${ }^{1}\left(\mathbb{D}\right.$, Afshin Parsaei ${ }^{1}\left(\mathbb{D}\right.$, Ali Khani Jeihooni ${ }^{2} \mathbb{D}$ \\ ${ }^{I}$ Department of Healthcare Management, Marvdasht Branch, Islamic Azad University, Marvdasht, Iran. ${ }^{2}$ Department of Public Health. School of Health, Fasa University of Medical Sciences, Fasa, Iran.
}

\section{ABSTRACT}

Objectives: Medical tourism refers to traveling to places where the individual could use medical services. Therefore, such a travel requires various activities in any of which the individual health is considered. Main samples of these types of travels include healthcare, beauty of organs, passing convalescence and rehabilitation, using hydrotherapy springs and good climate regions. The general objective of this study is to analyze the relation between digital marketing and medical tourism in point of view of Shiraz medical tourism policy makers.

Methods: This study is applied in respect of objective and in respect of collecting descriptive information it is of correlation studies type in which data collection was performed through library and field method. The statistical population of this study includes all strategic personnel and managers of Shiraz Medical Sciences University which is equal to 97. Regarding Cochran table for low number societies, the sample number was considered equal to the population. For collecting data, for the role of digital marketing in medical tourism industry from view of Shiraz medical tourism policy makers, scholar made questionnaire was used. This questionnaire includes 40 questions. The questionnaires were regulated based on 5-value Likert scale. Reliability and validity of this questionnaire was confirmed. For statistical techniques used for analysis of data obtained from the questionnaire, various statistical methods have been used. In the research descriptive section, descriptive statistical methods, relative frequency distribution and its percent diagrams have been used. And in the inferential statistics analysis, Kolmogorov- Smirnov test has been used for investigating data normality and then Pearson correlation factor and route analysis have been used

Results: The study results showed that there is a relation between digital marketing and medical tourism from viewpoint of Shiraz medical tourism policy makers. Also, there is a relation between factors relating to product or service, advertising, place, individuals, evidences and physical facilities and price and medical tourism from viewpoint of Shiraz medical tourism policy makers.

Conclusion: Study concludes that, educating usage of modern marketing methods and mixing them should be one of operational objectives of healthcare organization and this should be considered in educational planning.

Keywords: Digital marketing, health policy making, medical tourism, Shiraz.

Article Info: Received 18 December 2017; Revised 23 January; Accepted 18 February, Available online 15 March 2018

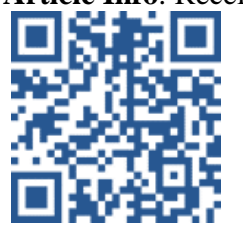

\section{Cite this article-}

Yazdanpanah A, Parsaei A, Jeihooni AK. The role of digital marketing in medical tourism industry in point of view of medical tourism policy makers of Shiraz in 2017. Universal Journal of Pharmaceutical Research. 2018; 3(1): 67-72.

DOI: http://doi.org/10.22270/ujpr.v3i1.R11

Address for Correspondence:

Abbas Yazdanpanah, Department of Healthcare Management, Marvdasht Branch, Islamic Azad University, Marvdasht, Iran. Email:abbas_yaz@miau.ac.ir.

\section{INTRODUCTION}

Today, tourism in various countries is considered the key force of the country economic growth and progress and by providing strategic opportunities, besides local prosperity causes employment and creating income and reducing poverty ${ }^{1,2,3}$. Due to significant of tourism and the role it plays in the progress of cultural, social and economic development ${ }^{4}$. At present, tourism industry has designated the place second great industry of the world. Considering the considerable location of tourism industry, this industry should have a strong and congruent to setting marketing. The stronger and more suitable the marketing management system, they will be more successful. Tourism marketing is an interactional process between providers and consumers (tourists) during which tourism goods and services which are special to this industry are exchanged ${ }^{5}$. In other words, tourism marketing is a new topic which points to identifying and predicting requirements of tourists and providing facilities for supplying needs and 
informing them and creating revisit motive in them ${ }^{5}$. Here, one of aspects which could be the origin of many evolutions for sustainable development of tourism industry is the exact identification of current status through tourism marketing. Intangibility, instability, heterogeneity, inseparability and non-possession are considered among important features of this service industry that reveal the necessity of using a combined model of marketing for tourism ${ }^{6-12}$. Seven foundations model of mixed marketing is a noteworthy topic in tourism industry that could be used in tourism industry for identifying the current status and reaching the optimal status.

Necessity and significance of the considered issue study is that medical sciences system plays a significant role in today societies. Since the organizations are the location of aggregation of many human and financial economic assets, they have a great potential for many works and efficiency and effectiveness of employees could help the organization $^{8}$. At present era people more than any other time use internet for searching information relating to travel, travel planning and purchasing travel services. Greenspan in a study has reported that tow third of internet users use online consultations for planning their travels ${ }^{9}$. Tourism information available in internet networks raise the awareness of tourists and leads to better planning and more optimal usage of people time and money. So, internet has turned a dominant media for searching information relating to tourism and this information search plays an important role in decision making process of tourists. In fact, this reality in today world that internet has turned to a channel for selling and marketing tourism industry has been accepted and we should confirm that one of the greatest differences of internet and modern media with traditional media is the possibility of providing informing possibility and providing services concurrently by this media, while the traditional media merely undertook the responsibility of informing ${ }^{10}$. Castaneda and Rodriguez showed that more people are satisfied with the information obtained from internet and this satisfaction includes both dimensions of satisfaction including satisfaction from the selected destination and satisfaction with the information obtained about the respective destination ${ }^{11}$. Advantages of tourism industry using internet includes cases such as global access, reducing costs, ease of updating information, more capability in conveying information to target addressees, creating the possibility of selecting respective product by the customers and so on. Modern media by facilitating active access to information have turned to an effective key in tourism industry and internet websites have turned to a suitable tool providing services ${ }^{13}$. Also, internet and modern media give this possibility to customers to compare information in a special field. When using internet, customers are able to cover all travel options, residential services and transportation, travel packages and so on and this type of information naturally helps tourists to plan for complex travels like long travels. Today, we could claim that internet has turned to the most important channel of providing tourism services which has led to deep changes in interaction with customers $^{14}$. Another aspect of internet network and modern media which has recently found popularity among people is weblogs and micro-weblogs that have created the possibility of updating writings, sharing pictures and even video files and the possibility of sending comment by viewers which have turned them to one of attractive phenomena for marketers which could also be used in tourism industry marketing ${ }^{15}$. Information technology and communication by creating wide possibility of searching information which is considered an important section of purchase decision making process, as internet achievement, not only has reduced risks but has raised the travels quality. In this regard, electronic marketing with the meaning of using digital and internet technologies such as electronic pots and websites have been created for selling tourism goods and services ${ }^{16}$. So that this type of marketing has been treated as a valuable lever for helping traditional marketing and regarding the nature of medical tourism in this field could be utilized as a suitable instrument ${ }^{17}$. This study investigates the relation between digital marketing and medical tourism from viewpoint of medical tourism policy makers and since no study has been performed under this title, so this study is distinguishable.

\section{METHODS}

This study is applied in respect of objective and in respect of collecting descriptive information it is of correlation studies type in which data collection was performed through library and field method. The statistical population of this study includes all strategic personnel and managers of Shiraz Medical Sciences University which is equal to 97 . Regarding Cochran table for low number societies, the sample number was considered equal to the population. For collecting data, for the role of digital marketing in medical tourism industry from view of Shiraz medical tourism policy makers, scholar made questionnaire was used. This questionnaire includes 40 questions.

The questionnaires were regulated based on 5-value Likert scale. Reliability and validity of this questionnaire was confirmed. For statistical techniques used for analysis of data obtained from the questionnaire, various statistical methods have been used. In the research descriptive section, descriptive statistical methods, relative frequency distribution and its percent diagrams have been used. And in the inferential statistics analysis, Kolmogorov- Smirnov test has been used for investigating data normality and then Pearson correlation factor and route analysis have been used ${ }^{18}$.

\section{RESULTS}

For using parametric tests for investigating the study hypothesis, the hypothesis ofvariables normality was declared using Kolmogorov- Smirnov method (by observing Table 1 and investigating significance of all subscales greater than 0.05). As it is observed in Table 2 , regarding correlation factor and significance level, there is a positive significant relation between all the study variables. 
As it is shown in Table 1, the intensity of impact of modern marketing variable in the medical tourism industry is 0.80 . Fitness indicators is one of the most important stages of modeling structural equations and this criterion shows that if the model shown by data confirms the research measurement model or not, the model indicator has been shown in Table 3 .

Table 1: The results of variables normality test.

\begin{tabular}{|c|c|c|}
\hline Sig & $\mathbf{Z}$ & Variable \\
\hline 0.268 & 0.421 & Modern marketing \\
\hline 0.97 & 1.101 & Medical tourism \\
\hline 0.109 & 0.398 & $\begin{array}{l}\text { Factors relating to } \\
\text { product or service }\end{array}$ \\
\hline 0.097 & 0.108 & $\begin{array}{l}\text { Factors relating to } \\
\text { advertisement }\end{array}$ \\
\hline 0.132 & 1.369 & Factors relating to place \\
\hline 0.205 & 0.362 & $\begin{array}{c}\text { Factors relating to } \\
\text { individuals }\end{array}$ \\
\hline 0.102 & 1.265 & $\begin{array}{l}\text { Factors relating to the } \\
\text { process of providing }\end{array}$ \\
\hline 0.241 & .0652 & $\begin{array}{c}\text { Factors relating to } \\
\text { physical evidences and } \\
\text { facilities }\end{array}$ \\
\hline 0.143 & 1.324 & Factors relating to price \\
\hline
\end{tabular}

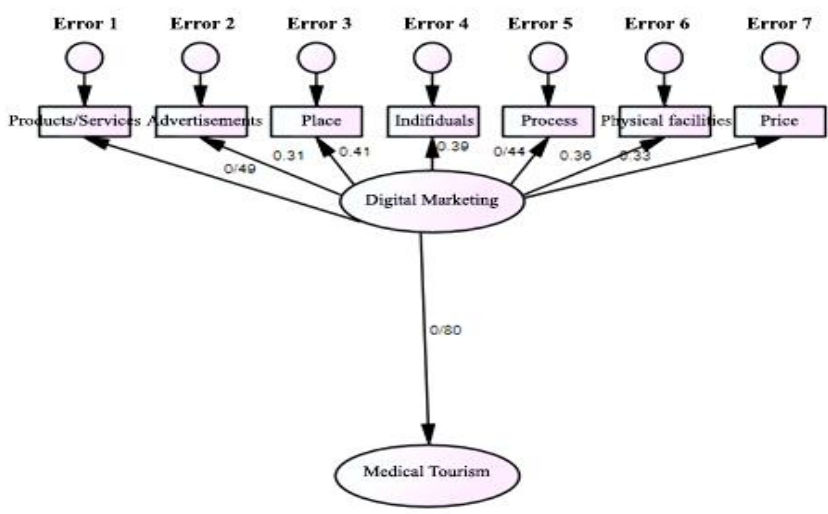

Figure 1: Digital marketing and error.

\section{DISCUSSION AND CONCLUSION}

This study seeks to answer these hypotheses that:

First hypothesis: there is a relation between digital marketing and medical tourism from view of Shiraz medical tourism policy makers. Regarding the correlation factor and significance level $(p=0.001$, $\mathrm{r}=0.810)$. There is a significant positive relation between digital marketing and status from viewpoint if Shiraz medical tourism policy makers. Therefore, based on the significance level, the study hypothesis is confirmed. This finding is consistent with the following studies: Hadson et al., Katler et al., Inskeep et al., Tsangand Chen et al., Esfahani et $a l^{19,20,21}$. Gholipour et al., in his study under the title of prioritizing factors effective on mixed marketing of hoteling industry by ranking method concluded that the price factor among other factors of hotel marketing has the highest priority in supplying customers' satisfaction $^{22}$. After price, respectively individuals, process, promotion, product, physical evidences and efficiency are in the next priorities. Kazemi et al., in his study under the title of investigating organizational citizens perception in Chabahar tourism development, stated that since tourism marketing in any country or a part of its depends on the buyers interests and perceptions, Zahedani citizens motive for traveling Chabahar is respectively cultural, commercial, physical activities, achieving peace, naturalism, luxuries and emotional ${ }^{7}$. Tsai et al., in their study under the title of the relation between advertisement and cultural tourist attraction in Iran stated that utilizing effective tools and factors in advertisement is among factors which could improve and develop the state tourism industry ${ }^{28}$. Using survey research method, they concluded that in view of cultural tourists the most important advertising tool for attracting cultural tourist respectively include: marketing, internet, book and articles about tourism attractions $^{25,26,27}$.

Second hypothesis: there is a relation between factors relating to product or service with medical tourism in view of Shiraz medical tourism policy makers. Regarding the correlation factor and significance level $(p=0.001, r=0.733)$, there is a significant and positive relation between factors relating to service or product and medial tourism. Therefore, based on the significance level, the study hypothesis is confirmed. Ghadiri Masoum et al., in their study evaluated and prioritized the factors influential on rural tourism marketing by P7 mixed model in Mazandaran province and concluded that indicators of advertisement, people and product in impacting rural tourism are more significant ${ }^{28,29,30}$. Barghi et al., in their study evaluated and ranked the indicators effective on rural tourism marketing using P7 mixed model in cities of Amol, Babol, Babolsar and Sari and concluded that components of advertisement, product and people have high priority in tourism marketing ${ }^{7}$. Farzin and Nadalipour et al., in their study under the title of factors effective on competitive advantage of tourism destinations in Iran regarding Chabahar city concluded that 5 factors of planning, destination policy, destination management, axial attractions, support resources and reinforcing factors are effective on tourism destinations $\mathrm{s}^{24,31,32,33}$

Third hypothesis: there is a relation between factors relating to advertising and medical tourism from point of view of Shiraz medical tourism policy makers. Regarding correlation factor and significance level $(p=0.001, \mathrm{r}=0.830)$, there is a significant and positive relation between factors relating to advertisement and medical tourism in view of Shiraz medical tourism policy makers. Therefore, based on the significance level, the research hypothesis is confirmed. Papoli et $a l$., in their study using previous literature, investigated tourism marketing philosophies and their application method in management of tourism marketing during various periods ${ }^{9}$. Uzama et al. in his study under the title of Japan tourism marketing using survey methods concluded that tourism development includes attention to development dimensions in all individual levels, guiding the assets, directing technology progress and structural and institutional change which is consistent with present and future needs of tourists ${ }^{31,34,35,36}$. 
Fourth hypothesis: there is a relation between factors relating to place and medical tourism from view of Shiraz medical tourism policy makers. Regarding the correlation factor and significance level $(p=0.001$, $\mathrm{r}=0.612)$, there is a significant and positive relation between factors relating to place and medical tourism from view of Shiraz medical tourism policy makers. Therefore, based on significance level, the study hypothesis is confirmed. Williams et al., in their study under the title of hospital tourism marketing, envision, feeling and amusement concluded that the status of historical places, ancient works; residential facilities and creating marketing offices and informing are among effective factors in development of tourism industry ${ }^{33}$. Woodside and Sakai in their study under the title of evaluating performance of governmental tourism marketing plans provided 4 proposals for plans evaluation:

Table 2: The results of Pearson correlation test.

\begin{tabular}{|c|c|c|}
\hline $\begin{array}{l}\text { Significance } \\
\text { level (p) }\end{array}$ & $\begin{array}{c}\text { Pearson } \\
\text { correlation } \\
\text { factor }(\mathbf{r})\end{array}$ & Statistical indicator and variable \\
\hline $0.001 *$ & $8100 /$ & $\begin{array}{c}\text { There is a relation between digital marketing and medical tourism from } \\
\text { viewpoint of Shiraz medical tourism policy makers }\end{array}$ \\
\hline $0.001 *$ & $7730 /$ & $\begin{array}{l}\text { There is a relation between factors relating to advertisement and medical } \\
\text { tourism from viewpoint of Shiraz medical tourism policy makers }\end{array}$ \\
\hline $0.001 *$ & $8300 /$ & $\begin{array}{l}\text { Between factors relating to place and medical tourism from viewpoint of Shiraz } \\
\text { medical tourism policy makers }\end{array}$ \\
\hline $0.001 *$ & $6120 /$ & $\begin{array}{l}\text { Between factors relating to individuals and medical tourism from viewpoint of } \\
\text { Shiraz medical tourism policy makers }\end{array}$ \\
\hline $0.001 *$ & $7130 /$ & $\begin{array}{l}\text { Between factors relating to physical evidences and facilities and medical } \\
\text { tourism from viewpoint of Shiraz medical tourism policy makers }\end{array}$ \\
\hline $0.001 *$ & $7700 /$ & $\begin{array}{l}\text { Between factors relating to process and medical tourism from viewpoint of } \\
\text { Shiraz medical tourism policy makers }\end{array}$ \\
\hline $0.001 *$ & $8230 /$ & $\begin{array}{l}\text { Between factors relating to physical facilities and evidences and medical } \\
\text { tourism from viewpoint of Shiraz medical tourism policy makers }\end{array}$ \\
\hline $0.001 *$ & $7030 /$ & $\begin{array}{l}\text { Between factors relating to price and medical tourism from viewpoint of Shiraz } \\
\text { medical tourism policy makers }\end{array}$ \\
\hline
\end{tabular}

Table 3: The content and research model general fitness indicators.

\begin{tabular}{|c|c|c|c|c|}
\hline $\begin{array}{l}\text { Acceptable } \\
\text { fitness }\end{array}$ & $\begin{array}{c}\text { Primary } \\
\text { model }\end{array}$ & Abbreviation & Name of indicator & $\begin{array}{c}\text { Indicators } \\
\text { categorizing }\end{array}$ \\
\hline Greater than 5\% & 20.12 & $\mathrm{X}^{2}$ & Qui-square covered level & \multirow{6}{*}{$\begin{array}{l}\text { Absolute } \\
\text { indicators of } \\
\text { fitness } \\
\text { Economic } \\
\text { indicators of } \\
\text { fitness }\end{array}$} \\
\hline GFI $>90 \%$ & 0.92 & GFI & Goodness of fit indicator & \\
\hline AGFI $>90 \%$ & 0.91 & AGFI & Modified goodness of fit indicator & \\
\hline Higher than $50 \%$ & 0.90 & PNFI & Normalized economic fitness indicator & \\
\hline RMSEA $<10 \%$ & 0.060 & RMSEA & Estimation error root square & \\
\hline Between $1-3$ & 1.42 & CMIN/df & $\begin{array}{l}\text { Normalized qui-square to freedom } \\
\text { degree }\end{array}$ & \\
\hline
\end{tabular}

Fifth hypothesis: there is a relation between factors relating to individuals and medical tourism from view of Shiraz medical tourism policy makers. Regarding correlation factor and significance level $(p=0.001$, $\mathrm{r}=0713$ ), there is a significant and positive relation between factors relating to individuals and medical tourism. Therefore, based on significance level, the hypothesis is confirmed ${ }^{37}$.

Sixth hypothesis: there is a relation between factors relating to process and medical tourism from view of Shiraz medical tourism policy makers. Regarding correlation factor and significance level $(p=0.001$, $\mathrm{r}=0.730$ ), there is a significant and positive relation between factors relating to process and medical
1. Continuous and formal training of plans evaluation,

2. Investigating both aspects of activities and plans,

3. Using multiple theories based on various paradigms for investigating performance of tourism marketing plans.

4. Changing the governmental marketing strategies form from one-sided to relational and participatory marketing.

Tsai et al., in their study under the title of place attachment and tourism marketing in Singapore international tourists using questionnaire concluded that the affinity of various places especially in respect of emotional features, cognitive motives, psychological growth and group awareness have a considerable impact on tourism marketing ${ }^{28}$. 
philosophies with order of marketing with origin of product, sale, customer and society. Eighth hypothesis: there is a relation between factors relating to price and medical tourism in view of Shiraz medical tourism policy makers. Regarding the correlation factor and significance level $(p=0.001, \quad \mathrm{r}=703)$ there is a significant and positive relation between factors relating to price and medical tourism. Therefore, based on the significance level, the hypothesis is confirmed. Gholipour et al. in their study under the title of prioritizing factors effective on mixed marketing of hostelling industry by ranking method concluded that the price factor among other factors of hotel marketing has the highest priority in supplying customers' satisfaction $^{35}$. After price, respectively individuals, process, promotion, product, physical evidences and efficiency are in the next priorities. Tsai et al. in their study under the title of the relation between advertisement and cultural tourist attraction in Iran stated that utilizing effective tools and factors in advertisement is among factors which could improve and develop the state tourism industry ${ }^{28}$. Using survey research method, they concluded that in view of cultural tourists the most important advertising tool for attracting cultural tourist respectively include: marketing, internet, book and articles about tourism attractions $^{28}$.

\section{AUTHOR'S CONTRIBUTION}

The manuscript was carried out, written, and approved in collaboration with all authors.

\section{ACKNOWLEDGEMENTS}

The authors extend their thanks and appreciation to the Islamic Azad University, Marvdasht, Iran to provide necessary facilities for this work.

\section{CONFLICT OF INTEREST}

No conflict of interest associated with this work.

\section{REFERENCES}

1. Ebrahimzadeh E, Masoumeh R, Daraei M. Optimal planning and locating facilities and infrastructures of urban tourism using GIS. Semnan City, Geography and development 2014; 35: 33-48. https://doi.org/10.15406/mojce.2017.03.00057

2. Eisa E, Yari M. comparative study of functions effective on tourists' behavioral pattern in marketing planning of Iran and America tourism using SWOT model. Tour space J 2011; 1(1): 1-26 https://doi.org/10.1016/j.tourman.2014.07.003

3. Zahra A, Abounoori A. Categorizing factors effective on economic indicators of foreign tourism, geography and development 2014; 34, 33-56.

4. Amin B, Ali A. Tourism industry in Iran, capabilities, obstacles and approaches, series of articles of national congress of capabilities, obstacles and approaches of developing tourism of Semnan province, Semnan Univeristy 2007

5. Amin B, Ali A, Zargar S, Mojtaba, Mashaallah N. Strategic marketing in tourism industry, strategic management studies 2010; 3, 49-68.

6. Amini S, Tavalaei S, Farjam R. Identifying and analyzing tourism in Shiraz city using extended Pourter model. Reg planning J 2011; 1(3), 1-16.

7. Barghi H, Kazemi Z, Souri F, Mosayebi S. Evaluating and ranking indicators effective on rural tourism marketing using P7 mixed model, regional planning J 2012; 2(6): 3141. https://doi.org/10.1016/j.tourman.2017.04.010

8. Behrouz. Investigating weakness and strengths, opportunity and threat of Iran tourism industry with impact on national production and employment with SWOT technique, $1^{\text {st }}$ electronic national congress of Iran economy perspective, 2013.

9. Papoli Y, Mohammad H, Saghaei M. Tourism (content and nature) Tehran, Samt publications, 2011. https://doi.org/ 10.4236/oje.2016.69050

10. Tavotli M, Mohammadi B. Investigating factors effective on tourism marketing in Kish Island, strategic scientific international congress of Iran tourism development, challenges and perspectives, Iran, Mashhad, 2014. https://doi.org/10.22270/ujpr.v3i1.R11

11. Hassanizadeh R. Research methods in behavioral sciences, Samt publications, Tehran, $1^{\text {st }}$ edition, 2008

12. Heidari R. Fundamentals of tourism industry planning, Samt Pubilcations. 2008; $1^{\text {st }}$ edition.

13. Khaki G. Research method with approach of writing thesis, Tehran, Samt publication. 2011; $1^{\text {st }}$ edition.

14. Khodadad H, Seyed H, Shirkhodaei M, Ahmadi P. Designing pattern of marketing preeminent in productive industries with combined approach, management studies in Iran 2011; 15(1): 209-230.

15. Danaei F, Hassan A, Seyed M, Azar A. Qualitative research methodology in management, comprehensive approach, Tehran, Safar Publication, 2010.

16. Amirtahmaseb S. The typology of inbound tourists visiting Iran (Doctoral dissertation, Master Thesis, Department of Business Administration and Social Sciences, Division of Industrial Marketing and E-Commerce, Lulea University of Technology, Lulea), 2007 https://doi.org/10.22270/ujpr.v3i1.R11

17. Arturo M, Mar G, David MC. Tourism marketing information and destination image management. African $\mathbf{J}$ Business Management 2010; 4(5): 722-728.

18. Bastic M, Gojcic S. Measurement scale for eco-component of hotel service quality. Int J Hospitality Manag 2012; 31(3): 1012-1020. https://doi.org/10.1016/j.ijhm.2011.12.007

19. Brown KG. Island tourism marketing: music and culture. Int J Culture Tourism Hosp Res 2009; 3(1): 25-32. https://doi.org/10.1016/j.tmp.2018.12.001

20. Chen CA. Suitable festival activities for Taiwan's tourism and nation branding with the application of the PR AHP program. Asia Pacific J Tourism Res 2013;1-18. https://doi.org/10.1080/10941665.2013.866579

21. Clarke J. Effective marketing for rural tourism. Rural Tourism Sust Bus 2005; 26, 87 . https://doi.org/10.21832/9781845410131-008

22. Enright MJ, Newton J. Tourism destination competitiveness: a quantitative approach. Tourism Manag 2004; 25(6): 777-788. https://doi.org/10.1016/j.tourman.2004.06.008

23. Esfahani N, Goudarzi M, Assadi H. The Annalysis of factors affecting the development, 2009.

24. Madasu P. Social media marketing and promotion of tourism. Management Insight 2013; 9(1). https://doi.org/10.1016/j.tmp.2014.01.001

25. Niavand A, Salarzehi H, Tash MNS. A Study of Strategic Role of Chabahar Free Zone on Tourism Industry Development Using SWOT Model in Iran. Int J Acad Res Business Social Sci 2014; 4(2): 202-216.

26. Thomas R, Huw T. Micro Politics and Micro Firms. J Small Bus Enter Dev 2006; 13 (1): 100-106

27. Tosun C, Okumus F, Fyall A. Marketing Philosophies: Evidence from Turkey. Annals Tourism Res 2008; 35(1): 127-147.https://doi.org/10.1016/S0160-7383(00)00078-5

28. Tsai SP. Place attachment and tourism marketing: Investigating international tourists in Singapore. Int J Tour Res 2012; 14(2): 139-152. https://doi.org/10.1002/jtr.842

29. Tsang SS, Chen YF. Facilitating Benchmarking with Strategic Grouping and Data Envelopment Analysis: The 
Case of International Tourist Hotels in Taiwan. Asia Pacific J Tour Res 2013; 18(5): 518-533.

https://doi.org/10.1080/10941665.2012.695283

30. UNWTO. World Tourism annual report. The World Tourism Organization, 2010.

31. Uzama A. Marketing Japans Tourism to the World. Paper presented at the annual conference of British association of Japanese studies in University of Manchester, 2008.

32. Vaiper MA, Akhlagh EM, Rafiee AA. The Effect of Social Marketing on Development of Ecotourism. J Novel Applied Sci 2014; 3(4): 376-381.

33. Williams A. Tourism Hospitality Marketing: Fantasy, Feeling and Fun. Int $\mathbf{J}$ Contemporary Hospitality Management 2006; 18 (6): 482-491. https://doi.org/10.1108/09596110610681520

34. Woodside AG, Sakai MY. Meta-evaluations of performance audits of government tourism-marketing programs. J Travel Research 2001; 39(4): 369-379.

35. Xu G. Tourism and local development in China: Case studies of guilin, Suzhou and Beidaihe. Routledge, 2013.

36. Zehrer A. Service Experience and Service Design. Managing Service Quality 2009; 19 (3): 332- 339. https://doi.org/10.1108/09604520910955339

37. Zhang $\mathrm{X}$, Song H, Huang GQ. Tourism supply chain management: A new research agenda. Tourism Management 2009; 30(3): 345-358.

https://doi.org/10.1016/j.tourman.2008.12.010 